\title{
ERCC1 is a prognostic biomarker in locally advanced head and neck cancer: results from a randomised, phase II trial
}

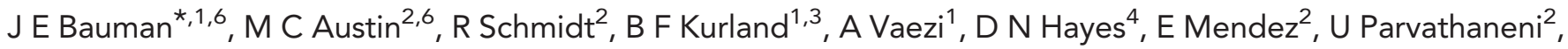 \\ X Chai ${ }^{3}$, S Sampath ${ }^{5}$ and R G Martins ${ }^{2}$ \\ ${ }^{1}$ Departments of Medicine, Biostatistics and Otolaryngology, University of Pittsburgh, Pittsburgh, PA, USA; ${ }^{2}$ Departments \\ of Pathology, Otolaryngology, Radiation Oncology and Medicine; University of Washington, Seattle, WA, USA; ${ }^{3}$ Department of \\ Clinical Statistics, Fred Hutchinson Cancer Research Center, Seattle, WA, USA; ${ }^{4}$ Department of Medicine, University of North \\ Carolina, Chapel Hill, NC, USA and ${ }^{5}$ Department of Radiation Oncology; City of Hope, Los Angeles, CA, USA
}

Background: Cisplatin-radiotherapy is a preferred standard for locally advanced, head and neck squamous cell carcinoma (HNSCC). However, the cisplatin-attributable survival benefit is small and toxicity substantial. A biomarker of cisplatin resistance could guide treatment selection and spare morbidity. The ERCC1-XPF nuclease is critical to DNA repair pathways resolving cisplatin-induced lesions.

Methods: In a phase II trial, patients with untreated Stage III-IVb HNSCC were randomised to cisplatin-radiotherapy with/without erlotinib. Archived primary tumours were available from 90 of 204 patients for this planned substudy. Semi-quantitative ERCC1 protein expression (H-score) was determined using the FL297, 4F9, and 8F1 antibodies. The primary analysis evaluated the relationship between continuous ERCC1 protein expression and progression-free survival (PFS). Secondary analyses included two pre-specified ERCC1 cutpoints and performance in HPV-associated disease.

Results: Higher ERCC1 expression was associated with inferior PFS, as measured by the specific antibodies FL297 (HR $=2.5,95 \%$ $\mathrm{Cl}=1.1-5.9, P=0.03)$ and 4F9 $(\mathrm{HR}=3.0,95 \% \mathrm{Cl}=1.2-7.8, P=0.02)$. Patients with increased vs decreased/normal ERCC1 expression experienced inferior PFS ( $H R=4.8$ for $F L 297, P=0.003 ; H R=5.5$ for $4 F 9, P=0.007$ ). This threshold remained prognostic in HPV-associated disease.

Conclusion: ERCC1-XPF protein expression by the specific FL297 and 4F9 antibodies is prognostic in patients undergoing definitive cisplatin-radiotherapy for HNSCC, irrespective of HPV status.

Head and neck cancer is the sixth leading cancer worldwide, with 600000 cases anticipated in 2012 (Kamangar et al, 2006; Siegel et al, 2012). Head and neck squamous cell carcinoma (HNSCC) accounts for more than $90 \%$ of incident cases. Despite advances in surgical and radiotherapy techniques, as well as integration of chemotherapy into multimodality treatment paradigms for HNSCC, 5-year overall survival (OS) is $40-60 \%$ and has increased only incrementally since 1990 (Jemal et al, 2010). The current standard of care for primary nonsurgical management of locally advanced HNSCC is concurrent cisplatin-radiotherapy, which

*Correspondence: Dr JE Bauman; E-mail: baumanje@upmc.edu

Portions of this biomarker study were presented in preliminary abstract form at the 2012 Annual Meeting of the American Society of Clinical Oncology, June 4-8, 2012, Chicago, IL and the 2013 Annual Meeting of the United States and Canada Academy of Pathology, March 2-8, 2013, Baltimore, MD.

${ }^{6}$ These authors contributed equally to this work

Received 22 May 2013; revised 20 August 2013; accepted 26 August 2013; published online 24 September 2013

(C) 2013 Cancer Research UK. All rights reserved 0007-0920/13 
significantly improved OS, progression-free survival (PFS), and locoregional control (LRC) compared with radiotherapy alone in the sentinel clinical trial, Intergroup 0126 (Adelstein et al, 2003). Similarly, concurrent cisplatin is indicated in the high-risk adjuvant setting (Bernier et al, 2004; Cooper et al, 2004). Although local control and overall survival (OS) are improved with concurrent platinum-based chemoradiotherapy, disappointing local and distant failure rates of $50 \%$ and $15 \%$, respectively, coupled with an absolute survival benefit of only $6.5 \%$ compared with radiotherapy alone suggest that only a subgroup benefits (Pignon et al, 2009). Given the considerable toxicities of cisplatin including nausea, hearing loss, nephrotoxicity, myelosuppression, and exacerbation of radiation effects such as mucositis and dysphagia (Henk, 1997; Adelstein et al, 2003; Trotti et al, 2003), the capacity to pre-select patients who would benefit is paramount.

Cisplatin [cis-diamminedichloroplatinum(II)] reacts with DNA to form adducts affecting either a single strand (the monoadduct or intrastrand crosslink) or two strands (the interstrand crosslink or ICL). These DNA lesions are, respectively, repaired by nucleotide excision repair (NER) or the distinct mechanism of ICL repair (Palom et al, 2002). ERCC1-XPF is a bipartite, structure-specific nuclease critical for both NER and ICL repair (De Silva et al, 2000). As such, ERCC1-XPF is the only enzyme required for removal of all cisplatin-induced DNA lesions. ERCC1 and XPF heterodimerise and stabilise each other in vivo; thus, expression levels tightly correlate (Niedernhofer et al, 2006), indicating that either protein may serve as a candidate biomarker for DNA repair capacity following cisplatin exposure.

In 2006, the International Adjuvant Lung Trial (IALT) bioinvestigator group retrospectively reported that low $v s$ high tumoural ERCC1 protein expression significantly predicted benefit from adjuvant cisplatin doublet chemotherapy in operable nonsmall cell lung cancer (NSCLC) (Olaussen et al, 2006). Robust results from a large randomised phase III trial generated intense interest in further development of ERCC1 as a predictive biomarker for platinum benefit. Initial enthusiasm was tempered by recognition that the antibody used in IALT, 8F1, was not specific for ERCC1 (Niedernhofer et al, 2007). Although 8F1 is able to immunoprecipitate ERCC1-XPF, it also tags a spurious $45 \mathrm{kDa}$ band on immunoblotting (Bhagwat et al, 2009), a cross-reaction that results in ERCC1-XPF-deficient cells being incorrectly characterised as having ERCC1-XPF expression. The second antigen recognised by $8 \mathrm{~F} 1$ may represent the unrelated nuclear membrane protein, PCYT $1 \alpha$, which shares a common epitope with ERCC1 (Ma et al, 2012). More troubling, the performance of 8F1 may have drifted over time; the IALT bio-investigator group recently controverted their original findings when unable to validate $8 \mathrm{~F} 1$ in a second cohort, nor reproduce their findings in the original IALT specimens (Friboulet et al, 2013).

Early reports in HNSCC also noted an association between high ERCC1 expression and inferior clinical outcomes after platinumbased therapy (Handra-Luca et al, 2007; Jun et al, 2008; Fountzilas et al, 2009; Chiu et al, 2011). However, results from these small, retrospective studies were inconsistently validated by others, possibly because the nonspecific 8F1 antibody was used (Koh et al, 2009; Hayes et al, 2011; Moeller et al, 2011). Two recent reports, using specific antibodies for ERCC1 or XPF, found that higher expression was associated with inferior PFS after cisplatinradiotherapy (Hao et al, 2011; Vaezi et al, 2011b). Preliminary findings suggested that ERCC1 expression may be of superior prognostic value in patients with tumours negative for human papillomavirus (HPV) (Hao et al, 2011). These hypothesisgenerating reports presented retrospective findings from patients treated in the routine clinical setting. Here, we present a planned analysis of tumoural ERCC1 expression from a randomised, phase II clinical trial of cisplatin-radiotherapy with or without erlotinib in locally advanced HNSCC (Martins et al, 2013a). We investigated the prognostic relationship of $8 \mathrm{~F} 1$ and two ERCC1-specific antibodies to PFS in a cohort treated homogeneously with cisplatin-radiotherapy, and followed prospectively for clinical outcomes. We further explored concordance of the three antibodies and performance in patients with HPV-associated HNSCC.

\section{MATERIALS AND METHODS}

Patients and specimens. A total of 204 patients were treated in the randomised phase II trial (ClinicalTrials.gov Registration: NCT00410826) between December 2006 and October 2011, with 105 patients enrolled in the standard arm (cisplatin-radiation) and 99 patients enrolled in the experimental arm (cisplatin-radiation with erlotinib $150 \mathrm{mg}$ daily; Martins et al, 2013a). Cisplatin was administered at $100 \mathrm{mg} \mathrm{m}^{-2}$ on days 1,22 , and 43 of radiotherapy to both patient groups. Radiation dose was $70 \mathrm{~Gy}$ in 35 fractions over 7 weeks with 3D conformal techniques or its equivalent with intensity modulated radiotherapy. Randomisation was stratified by center and degree of nodal involvement (N0/1 vs N2/3). The primary end point was complete response rate (CRR) following chemoradiotherapy; secondary endpoints were PFS and OS. For this biomarker study, formalin-fixed paraffin-embedded (FFPE) pre-treatment primary tumour tissue was analysed when patients provided consent and tissue was available.

ERCC1 evaluation. Pre-cut slides sectioned at $4 \mu$ thickness were autostained using standard immunohistochemistry (IHC) protocols on Leica Bond III immunostainers (Leica Microsystems Inc, Buffalo Grove, IL, USA) according to the manufacturer's operating instructions. Three distinct ERCC1 antibodies were used, including an 8F1 monoclonal antibody (1:400 dilution, Neomarkers, Kalamazoo, MI, USA), a 4F9 monoclonal antibody $(1: 200$ dilution, OriGene, Rockville, MD, USA), and an FL297 polyclonal antibody (1:50 dilution, Santa Cruz Biotechnology Inc., Santa Cruz, CA, USA). Antigen retrieval was effected by heat-induced epitope retrieval (HIER) using Tris-EDTA for $20 \mathrm{~min}$. The slides were then incubated at room temperature for $15 \mathrm{~min}$ ( $8 \mathrm{~F} 1$ and $4 \mathrm{~F} 9$ ) or $60 \mathrm{~min}$ (FL297). Four micron-thick sections of normal and neoplastic lung tissue were included as external positive controls. Basal epithelial cells in normal tissue adjacent to each tumour served as an internal positive control. At the time of ERCC1 staining, the ultra-specificity of 4F9 had not yet been reported in the published literature (Ma et al, 2012). Thus, the 4F9 antibody was evaluated for specificity against ERCC1 by western blot, immunofluorescence, and IHC techniques in normal and XPFERCC1-deficient human fibroblasts as previously described (Niedernhofer et al, 2007; Bhagwat et al, 2009). XP2YO cells were used because they have only a trace amount of ERCC1 and are an accepted reagent to assess antibody specificity for ERCC1 (Niedernhofer et al, 2007; Bhagwat et al, 2009). D10 and 8F1 were used as ERCC1-specific and non-specific control antibodies, respectively, as previously characterised (Bhagwat et al, 2009).

A single pathologist (MA) blinded to outcomes evaluated all IHC staining under a light microscope at a magnification of $\times 400$. A semi-quantitative $\mathrm{H}$-score (expression $\mathrm{x}$ intensity) was calculated for ERCC1 expression. To overcome variance in pre-analytic processing including differences in cold ischemia time, formalin fixation, processor protocols, and storage that likely differed among sites, staining intensity was assigned with reference to an internal control. Specifically, the staining intensity of the nuclei of non-neoplastic basal epithelial cells (internal control, present in all samples) was designated normal or $2+$, as previously described (Handra-Luca et al, 2007). The staining intensity of tumour cell nuclei was compared with the internal control with 0 representing no staining, $1+$ representing decreased, $2+$ representing 
equivalent, and $3+$ representing increased. Fifty neoplastic cells from three separate areas of each slide were counted. The percentage of cells staining for ERCC1 (see Figure 1) was assigned a weighted expression score as described (None $=0,1-9 \%=0.1$, $10-49 \%=0.5$, and $50-100 \%=1$ ) (Olaussen et al, 2006; HandraLuca et al, 2007). In tumours with heterogeneous ERCC1 staining, multiple representative areas were scored; staining intensity was assigned as a weighted sum rounded to the nearest quartile. For example, if $60 \%$ of cells stained for ERCC1 and the proportion of cells staining $3+v s 2+$ was $70: 30$, the $\mathrm{H}$-score was calculated as weighted expression $(1) \times$ weighted intensity $(2.75)=2.75$.
Although previous studies commonly used the H-score median split to define increased $v s$ decreased ERCC1 expression (HandraLuca et al, 2007; Hao et al, 2011), the use of an internal control allowed pre-definition of three categorical $\mathrm{H}$-scores potentially applicable across study populations: 'decreased expression' (H-score $\leqslant 1.5)$, 'normal expression' $(1.5<\mathrm{H}$-score $<2.5)$, and 'increased expression' (H-score $\geqslant 2.5)$. These categorical thresholds were defined empirically: 1.5 corresponded to the mathematical point where the majority of tumour cells had decreased ERCC1 staining and, similarly, 2.5 corresponded to the mathematical point where the majority of tumour cells had increased staining.
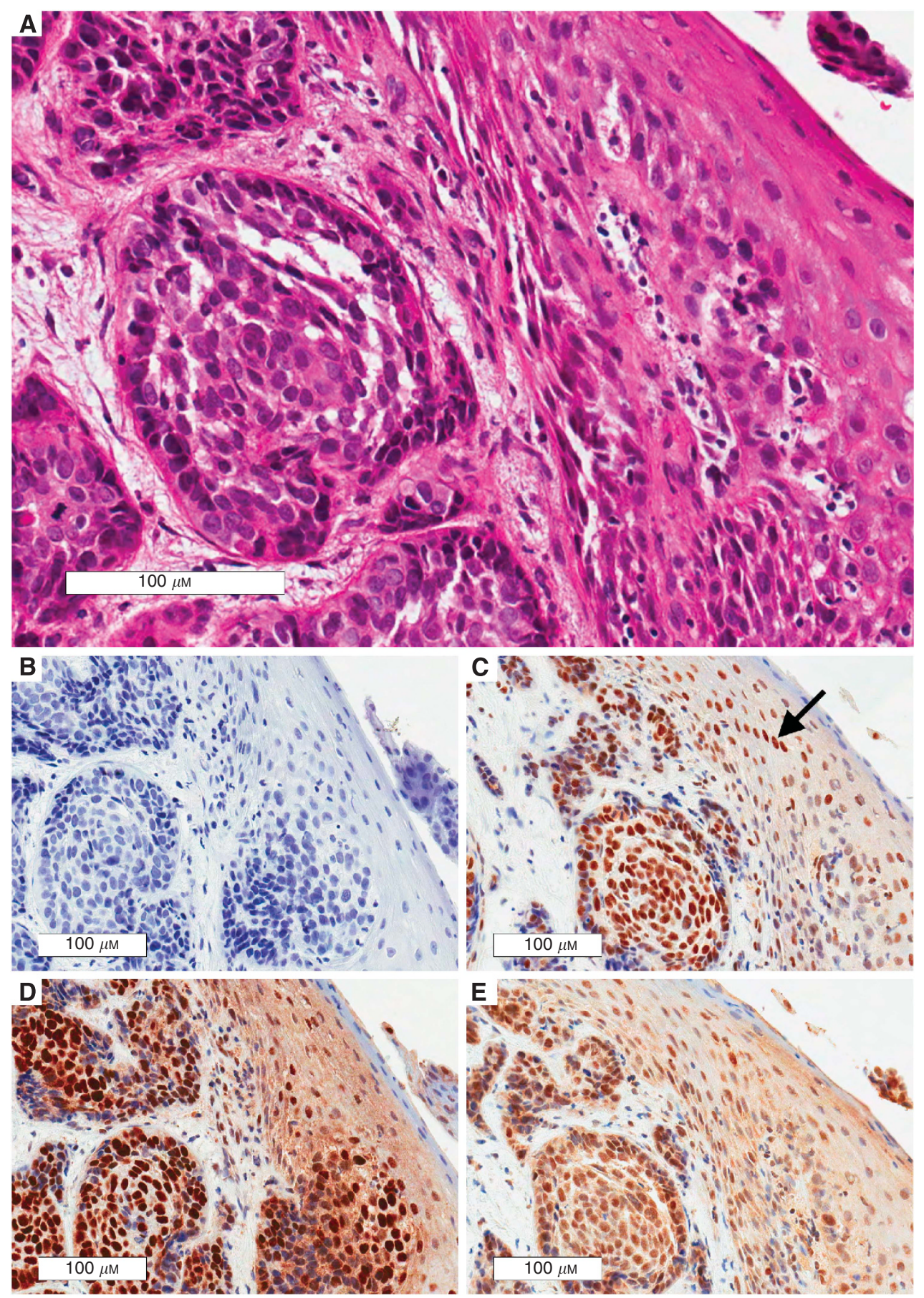

Figure 1. Representative 3+ ERCC1 Staining for FL297, 4F9, and 8F1. Representative ERCC1 stains are presented for consecutive sections of a p16-negative hypopharynx tumour. Note that staining intensity cannot be compared among antibodies as it is referenced to an internal control designated $2+$ (arrow in box C). (A) H\&E stained invasive squamous cell carcinoma at $\times 20$ magnification. (B) Negative control; tissue shows lack of non-specific ERCC1 staining. (C) $3+$ ERCC1 staining for 4F9. (D) $3+$ ERCC1 staining for 8F1. (E) $3+$ ERCC1 staining for FL297. 
p16 evaluation. Overexpression of the p16 cell cycle protein is the accepted surrogate for HPV infection, an established prognostic biomarker in oropharyngeal HNSCC (Ang et al, 2010). To assess p16, pre-cut slides sectioned at $4 \mu$ thickness were auto-stained using standard immunohistochemistry (IHC) protocols on Leica Bond III immunostainers according to the manufacturer's operating instructions. Antigen retrieval was effected by HIER using Tris-EDTA for $20 \mathrm{~min}$. The slides were then incubated at room temperature for $30 \mathrm{~min}$ with an undiluted CINTec p16 antibody (MTM Labs AG, Ventana Medical Systems Inc., Tucson, AZ, USA). Four micron-thick sections of cervical intraepithelial neoplasia II tissue were included as external positive controls.

In accordance with standard grading criteria, p16-positivity was defined as tumours with $\geqslant 70 \%$ of neoplastic cells demonstrating strong and diffuse nuclear and cytoplasmic staining (Jordan et al, 2012). All available tumours were stained for p16, regardless of anatomic site. However, only p-16-positive oropharynx tumours were classified as HPV-associated.

Statistical analysis. The sample size for this analysis was determined by tissue availability. Assuming an exponential survival function and median PFS of 18 months for patients with higher risk of relapse/death (Ang et al, 2010), a study accruing 24 patients per year for 3.75 years $(n=90)$, with an additional 6 months of follow-up, would have $\sim 91 \%$ power for a two-sided test to detect a hazard ratio of 3.0 , if $50 \%-67 \%$ of patients have a lower risk of relapse. Power would be $82 \%$ to detect a hazard ratio of 2.5 .

The primary statistical analysis evaluated the association between ERCC1 expression and PFS by Cox proportional hazards regression, stratified by randomisation strata and controlling for treatment arm. Formal hypothesis testing was planned only for the specific FL297 and 4F9 antibodies, to limit overall Type I error, with alpha set at 0.05 . Although the primary statistical analysis considered ERCC1 $\mathrm{H}$-scores as continuous variables, the three pre-specified ERCC1 expression categories were used for graphical display. Categorical ERCC1 expression also permitted preliminary investigation of two pre-defined cutpoints (decreased vs normal/increased; decreased/normal vs increased), for future investigation of ERCC1 expression as an integral prospective biomarker. To minimise false discovery, no other cutpoints were tested.

Agreement among ERCC1 expression assays was assessed using Bland-Altman plots and summarised by the concordance correlation coefficient, using the SAS \%CCC macro (Barnhart et al, 2002; Crawford et al, 2007). Associations between ERCC1 and p16 expression and other prognostic factors, and their independent or combined associations with PFS, were also explored. A Wilcoxon rank-sum test was used to evaluate ERCC1 expression in association with p16 status. Additional comparisons between categorical variables were conducted using $\chi^{2}$-tests of association. Kaplan-Meier curves were used for graphical illustrations of associations between PFS and markers. Statistical tests were two-sided, and analyses were conducted using the SAS/ STAT software version 9.3 (SAS Institute, Inc., Cary, NC, USA) and $\mathrm{R}$ version 2.15.0 ( $\mathrm{R}$ Foundation for Statistical Computing, Vienna, Austria).

\section{RESULTS}

Clinical outcomes. In the parent trial, clinical outcomes did not differ according to the treatment arm, including the primary end point of CRR and the secondary end point of PFS (Martins et al, $2013 \mathrm{~b}$ ). The CRR according to standardised protocol criteria was $40 \%$ vs $52 \%$ on the standard vs experimental arm $(P=0.08)$.
With a median follow-up of 26 months, there was no difference in PFS $(\mathrm{HR}=0.9, P=0.71)$. The primary biomarker analysis therefore did not control for treatment-by-marker interactions, which were not statistically significant and had little effect on parameter estimates or inference for ERCC1 effects.

Specificity of 4F9. The 4F9 monoclonal antibody was found to be specific for ERCC1. By western blot on XP2YO cell lysates, or by immunofluorescence and IHC on XP2YO cells, 4F9 demonstrated only background signal in the ERCC1-XPF-deficient cells (Figure 2).

ERCC1 expression. Sufficient analysable tissue was submitted from 90 patients consenting to optional tissue correlatives. Table 1 summarises the characteristics of patients with and without available tissue. Tissue assessment did not differ by treatment arm, sex, smoking status, or other demographic characteristics. There was a nonsignificant tendency for tissue to be available for patients with higher T-stage $(P=0.09)$, and patients classified with oral cavity or overlapping primary site were less likely to have tissue available as compared with pharyngeal or laryngeal sites $(P=0.009)$.

We evaluated marker prevalence for $8 \mathrm{~F} 1$ and two specific antiERCC1 antibodies, FL297 and 4F9 (Table 2). IHC was performed for all three ERCC1 antibodies in 88 of 90 tumours, limited by tissue availability. The majority of tumours was p16 positive, including 50 oropharyngeal $(50 / 64,78 \%)$ and 6 non-oropharyngeal tumours (6/26, 23\%). Approximately half of tumours demonstrated increased ERCC1 expression, relative to internal control, with each antibody. The 4F9 and FL297 assays showed good agreement with a concordance correlation coefficient (CCC) of 0.88 (95\% CI 0.82-0.92). The 8F1 antibody demonstrated a higher percentage of tumours with decreased ERCC1 staining and had modest concordance with the $4 \mathrm{~F} 9(\mathrm{CCC}=0.53,95 \% \mathrm{CI} 0.37-0.66)$ and FL297 (CCC $=0.44$, 95\% CI 0.26-0.59) antibodies. Concordance of ERCC1 assays is displayed by Bland-Altman plots in Figure 3.

ERCC1 and PFS. Table 3A presents the primary results from Cox proportional hazards models, examining the association between the three ERCC1 assays and PFS, stratified by randomisation strata and controlling for treatment arm. Higher ERCC1 expression was associated with a greater hazard of progression or death, as measured using the FL297 ( $\mathrm{HR}=2.5,95 \% \mathrm{CI} 1.1-5.9)$ and $4 \mathrm{~F} 9$ assays $(\mathrm{HR}=3.0,95 \% \mathrm{CI} 1.2-7.8)$, but not the $8 \mathrm{~F} 1$ assay $(\mathrm{HR}=1.4,95 \% \mathrm{CI} 0.8-2.5)$. To graphically illustrate the associations between ERCC1 expression and PFS, Kaplan-Meier plots using three pre-specified expression categories (decreased, normal, increased) are presented in Figure 4.

Exploratory analysis of two pre-specified categorical cutpoints for ERCC1 expression (decreased $v s$ normal/increased or decreased/normal $v s$ increased), as measured by the specific antibodies FL297 and 4F9, indicated that patients with increased tumoural expression were at significantly greater risk for progression or death compared with patients with decreased/normal expression $(\mathrm{HR}=4.8$ for increased FL297 ERCC1 expression, $P=0.003 ; \quad H R=5.5$ for increased $4 \mathrm{~F} 9$ expression, $P=0.007$; Table 3B).

ERCC1 and known prognostic factors. Overexpression of the p16 cell cycle protein, a consequence of the degradation of retinoblastoma by the HPV E7 oncoprotein, is indicative of biologically relevant HPV infection and serves as a prognostic biomarker in oropharyngeal HNSCC (Ang et al, 2010). Associations between p16 status and ERCC1 were therefore analysed by the Wilcoxon rank-sum test for FL297 and 4F9 (Figure 5). For both antibodies, there was a significant trend for ERCC1 expression to be higher in p16-negative than in p16-positive tumours, although all categorical expression levels were observed in both. In the 33 

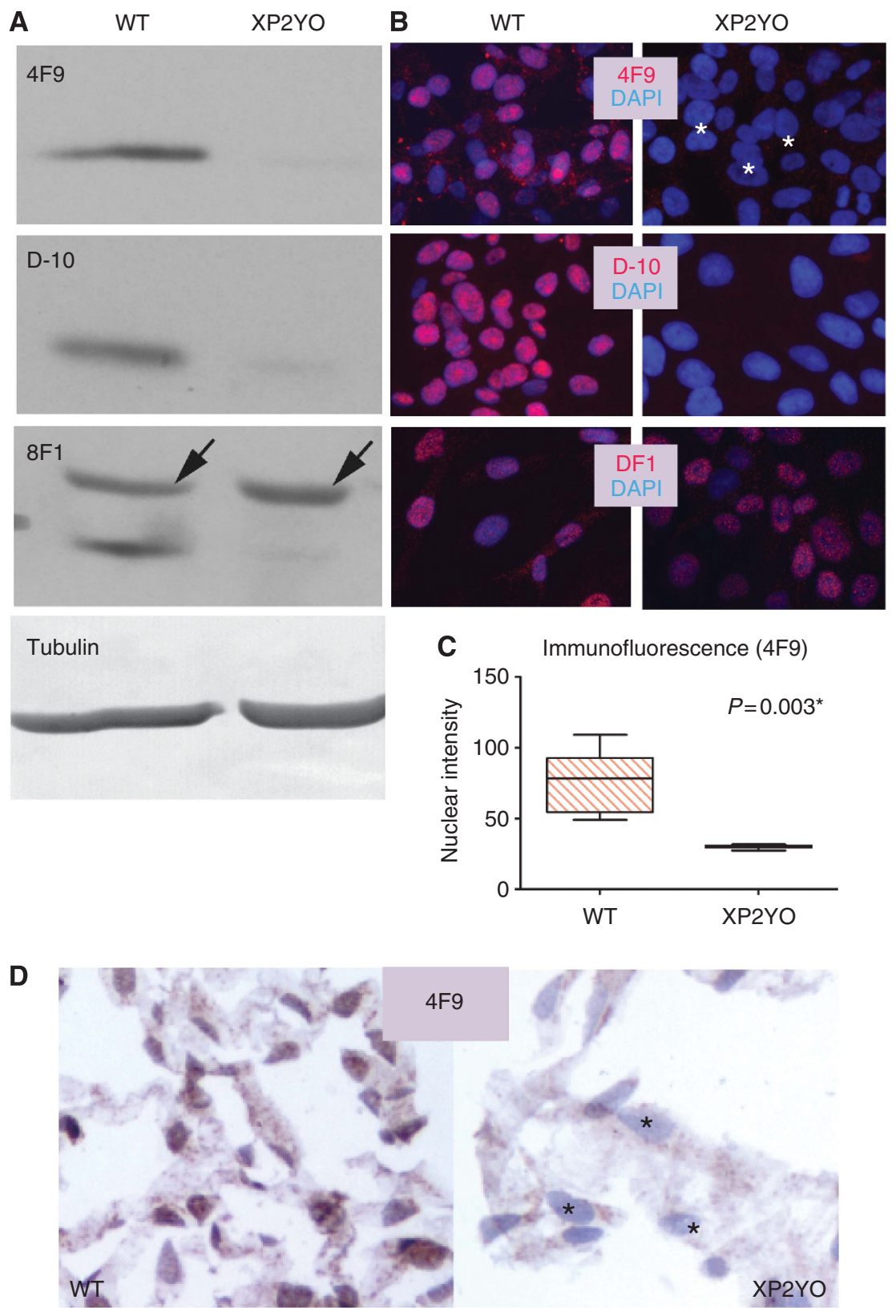

Figure 2. The 4F9 antibody is specific for ERCC1. Specificity of 4F9 is assessed in human skin fibroblasts isolated from either a normal individual (WT) or an individual with a mutation in XPF causing near-undetectable ERCC1 (XP2YO). (A) 4F9 is specific by western blot. Only a trace amount of ERCC1 is detected in XP2YO cells with either 4F9 or the specific anti-ERCC1 antibody D-10. In contrast, the non-specific 8F1 antibody recognises an additional band migrating slightly slower than ERCC1, present both in WT and ERCC1 deficient cells (arrows). Tubulin (loading control). (B) 4F9 is specific by immunofluorescence. Only background nuclear signal is observed in ERCC1-deficient cells either with 4F9 (white asterisks) or with the antibody D-10 while nuclear staining is readily observable in WT cells. In contrast, the nuclear signal persists in ERCC1 deficient cells when 8F1 is used, confirming the lack of specificity of this antibody. ERCC1 antibodies (red); DNA stain DAPI (blue). (C) Quantitation of average nuclear fluorescence intensity represented by boxplot; $\mathrm{p}$ (paired $t$-test); * indicates statistical significance. (D) $4 \mathrm{F9}$ is specific by immunohistochemistry performed on formalin-fixed paraffin-embedded cells. Only background staining is observed in ERCC1-deficient cells (black asterisks). 4F9 (brown); haematoxylin counterstain (blue).

p16-negative tumours, the proportion of (decreased/normal/ increased) ERCC1(FL297) expression was 12\%, 27\%, 61\%, compared with $15 \%, 49 \%, 36 \%$ in 55 p16-positive tumours. Proportions were similar for 4 F9. Associations between the two specific ERCC1 antibodies and PFS were not altered substantially by controlling for p16 status (p16-positive oropharyngeal tumour vs other; Table 3C). Data were too sparse to estimate an ERCC1by-p16 interaction term.

The primary analysis (Table $3 \mathrm{~A}$ ) accounted for N-stage, a known prognostic factor, as part of randomisation strata. Another known prognostic factor, T-stage (T1/2 vs T3/4), did not contribute to predicting PFS in secondary models accounting for ERCC1 assays and randomisation stratum (models not shown).

An exploratory analysis of PFS by ERCC1 restricted to patients with p16-positive oropharyngeal tumours was performed to isolate whether ERCC1 may be prognostic in HPV-associated HNSCC as currently defined. Supplementary Figure 1 suggests that ERCC1 as detected by the specific antibodies FL297 and 4F9 remained significantly prognostic. 


\begin{tabular}{|c|c|c|c|}
\hline & $\begin{array}{c}\text { Study } \\
\text { sample: } \\
\text { tissue } \\
\text { available } \\
(n=90)\end{array}$ & $\begin{array}{l}\text { Randomised } \\
\text { trial patients: } \\
\text { tissue } \\
\text { unavailable } \\
(n=114)\end{array}$ & $P$-value $\left(\chi^{2}\right)$ \\
\hline Treatment group & & & 0.51 \\
\hline $\begin{array}{l}\text { Chemoradiation } \\
\text { Chemoradiation + erlotinib }\end{array}$ & $\begin{array}{l}49 \% \\
51 \%\end{array}$ & $\begin{array}{l}54 \% \\
46 \%\end{array}$ & \\
\hline Sex & & & 0.56 \\
\hline $\begin{array}{l}\text { Male } \\
\text { Female }\end{array}$ & $\begin{array}{l}88 \% \\
12 \%\end{array}$ & $\begin{array}{l}85 \% \\
15 \%\end{array}$ & \\
\hline Race & & & 0.81 \\
\hline $\begin{array}{l}\text { White } \\
\text { Black or African-American } \\
\text { American Indian or Alaska } \\
\text { Native } \\
\text { Asian } \\
\text { Other } \\
\text { Unknown }\end{array}$ & $\begin{array}{r}82 \% \\
16 \% \\
0 \% \\
\\
1 \% \\
0 \% \\
1 \%\end{array}$ & $\begin{array}{r}80 \% \\
14 \% \\
1 \% \\
\\
3 \% \\
1 \% \\
1 \%\end{array}$ & \\
\hline Ethnicity & & & 0.50 \\
\hline $\begin{array}{l}\text { Hispanic } \\
\text { Not Hispanic } \\
\text { Unknown }\end{array}$ & $\begin{array}{r}11 \% \\
88 \% \\
1 \%\end{array}$ & $\begin{array}{r}10 \% \\
90 \% \\
0 \%\end{array}$ & \\
\hline Smoking status & & & 0.87 \\
\hline $\begin{array}{l}\text { Current } \\
\text { Former } \\
\text { Never }\end{array}$ & $\begin{array}{l}26 \% \\
51 \% \\
23 \%\end{array}$ & $\begin{array}{l}23 \% \\
54 \% \\
23 \%\end{array}$ & \\
\hline Primary site & & & $0.009^{*}$ \\
\hline $\begin{array}{l}\text { Hypopharynx } \\
\text { Larynx } \\
\text { Nasopharynx } \\
\text { Oral Cavity } \\
\text { Oropharynx } \\
\text { Overlapping }\end{array}$ & \begin{tabular}{r|r|}
$6 \%$ \\
$20 \%$ \\
$2 \%$ \\
$1 \%$ \\
$71 \%$ \\
$0 \%$
\end{tabular} & \begin{tabular}{r|}
$6 \%$ \\
$16 \%$ \\
$0 \%$ \\
$12 \%$ \\
$62 \%$ \\
$4 \%$ \\
\end{tabular} & \\
\hline T Stage & & & 0.09 \\
\hline $\begin{array}{l}\text { T1 } \\
\text { T2 } \\
\text { T3 } \\
\text { T4 }\end{array}$ & $\begin{array}{l}10 \% \\
23 \% \\
37 \% \\
30 \%\end{array}$ & $\begin{array}{r}5 \% \\
37 \% \\
38 \% \\
20 \%\end{array}$ & \\
\hline N Stage & & & 0.10 \\
\hline $\begin{array}{l}\text { N0 } \\
\text { N1 } \\
\text { N2 } \\
\text { N3 }\end{array}$ & $\begin{array}{r}15 \% \\
10 \% \\
67 \% \\
8 \%\end{array}$ & $\begin{array}{r}6 \% \\
18 \% \\
69 \% \\
7 \% \\
\end{array}$ & \\
\hline
\end{tabular}

\section{DISCUSSION}

In a randomised clinical trial cohort of patients with locally advanced HNSCC treated with high-dose cisplatin-radiotherapy with or without erlotinib, ERCC1 protein expression level assayed by the specific ERCC1 antibodies FL297 and 4F9 was prognostic: patients with higher tumoural expression experienced significantly inferior PFS. This relationship was significant both in proportional hazards regression with ERCC1 defined as a continuous variable and when the study population was divided into 'increased' $v s$ 'decreased/normal' expression by a predefined binary cutpoint with potential clinical utility. This conclusion is further strengthened by prospective collection of clinical outcomes in the context of a clinical trial, sample size, homogeneity of exposure to cisplatin and radiotherapy, and concordant results from two specific ERCC1 antibodies. Similar to a recent retrospective series, the nonspecific $8 \mathrm{~F} 1$ antibody was not found to be prognostic (Hao et al, 2011).
Table 2. Summary of marker prevalence

\begin{tabular}{|c|c|c|c|}
\hline Marker & $\mathrm{N}$ & $\mathrm{N}(\%)$ & Median (min-max) \\
\hline p16 & 90 & & \\
\hline $\begin{array}{l}\text { Positive } \\
\text { Negative }\end{array}$ & & $\begin{array}{l}56(62 \%) \\
34(38 \%)\end{array}$ & \\
\hline p16 (Oropharynx) & 64 & & \\
\hline $\begin{array}{l}\text { Positive } \\
\text { Negative }\end{array}$ & & $\begin{array}{l}50(78 \%) \\
14(22 \%)\end{array}$ & \\
\hline p16 (Non-oropharynx) & 26 & & \\
\hline $\begin{array}{l}\text { Positive } \\
\text { Negative }\end{array}$ & & $\begin{array}{r}6(23 \%) \\
20(77 \%)\end{array}$ & \\
\hline ERCC1 (FL297) & 88 & & $2.25(0.1-3.0)$ \\
\hline $\begin{array}{l}\text { Decreased }^{\text {a }} \\
\text { Normal }^{\text {a }} \\
\text { Increased }^{a}\end{array}$ & & $\begin{array}{l}12(14 \%) \\
36(41 \%) \\
40(45 \%)\end{array}$ & \\
\hline ERCC1 (4F9) & 88 & & $2.5(0.1-3.0)$ \\
\hline $\begin{array}{l}\text { Decreased } \\
\text { Normal }^{a} \\
\text { Increased }^{a}\end{array}$ & & $\begin{array}{l}14(16 \%) \\
26(30 \%) \\
48(54 \%)\end{array}$ & \\
\hline ERCC1 (8F1) & 90 & & $2.25(0.1-3.0)$ \\
\hline $\begin{array}{l}\text { Decreased }^{a} \\
\text { Normal }^{a} \\
\text { Increased }^{a}\end{array}$ & & $\begin{array}{l}30(33 \%) \\
18(20 \%) \\
42(47 \%)\end{array}$ & \\
\hline
\end{tabular}

The ERCC1-XPF nuclease is the only DNA repair enzyme critical to both NER and ICL repair, thus is an attractive candidate biomarker for cisplatin resistance. The challenge in oncology has been validation of a measurement technique that correlates with DNA repair capacity, applies to available FFPE tissue specimens or peripheral blood, and predicts a relevant clinical outcome. Aspiring methodologies include single-nucleotide polymorphisms (SNPs) in the ERCC1-XPF gene, quantification of tumoural ERCC1 mRNA, and semi-quantitative ERCC1-XPF protein expression by IHC. Although SNPs are appealing due to ease of acquiring germline DNA through peripheral blood, no SNP has emerged as a consistent predictor of HNSCC risk or treatment response (Vaezi et al, 2011a). ERCC1 mRNA is measurable with RT-PCR in FFPE specimens as a surrogate for ERCC1-XPF function and demonstrates promise in tailoring platinum chemotherapy in advanced NSCLC (Simon et al, 2012). However, because of post transcription processing, ERCC1 mRNA does not consistently correlate with protein expression(Britten et al, 2000; Zheng et al, 2007), and was not associated with response or survival in HNSCC patients undergoing cisplatin-radiotherapy (Hao et al, 2011). Because of lack of correlation with prognosis in antecedent studies, ERCC1 SNPs and mRNA were not evaluated here.

In HNSCC, the most promising measurement technique for predicting outcome from cisplatin-based therapy has been expression level of ERCC1-XPF protein by semi-quantitative IHC. Immunodetection faces several methodologic challenges including geographic variation in protein expression within a tumour (Taillade et al, 2007) pre-analytic variables such as collection, tissue processing/fixation protocols, and storage (Babic et al, 2010); and rates of interobserver agreement (Taylor and Levenson, 2006). In HNSCC, clinical development of an ERCC1XPF biomarker also has been impaired by recognition of the nonspecificity of 8F1 (Niedernhofer et al, 2007), used in the majority of early retrospective studies, and the inconsistent association of $8 \mathrm{~F} 1$ with PFS. In the current study, we confirmed that $8 \mathrm{~F} 1$ was not 
ERCC1(FL297) vs ERCC1(4F9)

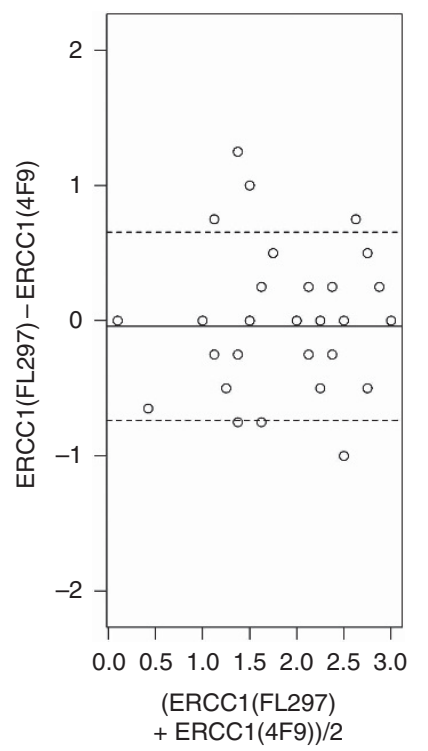

ERCC1(FL297) vs ERCC1(8F1)

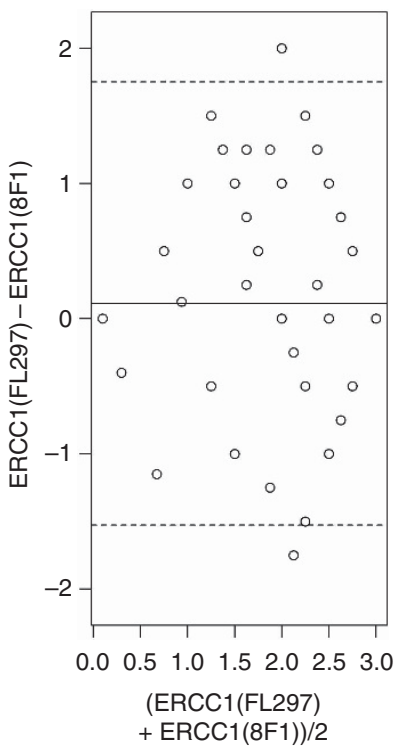

ERCC1(4F9) vs ERCC1(8F1)

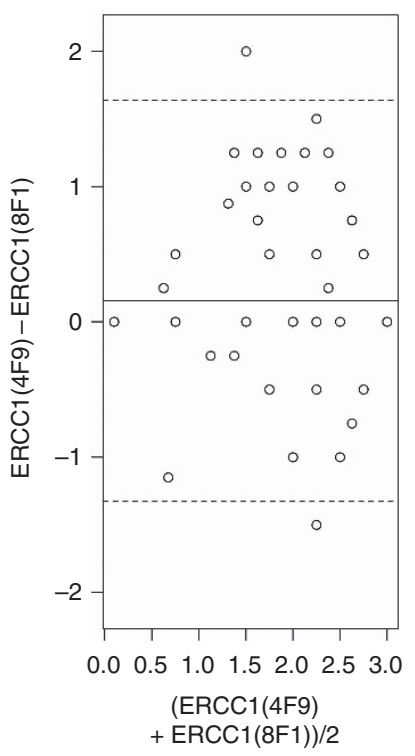

Figure 3. Bland-Altman plots comparing $\mathrm{H}$-scores for three ERCC1 assays. Mean differences were centered around zero for all assays (solid lines), but $95 \%$ limits of agreement (dashed lines) were more narrow for the FL297 and 4F9 antibodies.

\section{Table 3. Cox proportional hazard regression for ERCC1 expression by PFS}

\begin{tabular}{|c|c|c|c|c|c|c|}
\hline & \multicolumn{2}{|c|}{ ERCC1 (FL297) $\mathbf{N}=88$} & \multicolumn{2}{|l|}{ ERCC1 (4F9) $N=88$} & \multicolumn{2}{|l|}{ ERCC1 (8F1) $\mathbf{N}=90$} \\
\hline & Estimate $(95 \% \mathrm{Cl})$ & $P$-value & Estimate $(95 \% \mathrm{Cl})$ & $\boldsymbol{P}$-value & Estimate $(95 \% \mathrm{Cl})$ & $P$-value \\
\hline \multicolumn{7}{|l|}{ A. Continuous ERCC1 expression } \\
\hline Hazard ratio (e.g. H-score of 3 vs 2 or 2 vs 1 ) & $2.5(1.1-5.9)$ & $0.03^{*}$ & $3.0(1.2-7.8)$ & $0.02^{*}$ & $1.4(0.8-2.5)$ & 0.21 \\
\hline \multicolumn{7}{|c|}{ B. ERCC1 expression categorised by pre-determined H-score cutpoints ${ }^{a}$} \\
\hline \multicolumn{7}{|l|}{ Hazard ratio } \\
\hline $\begin{array}{l}\text { Normal/increased vs decreased } \\
\text { Increased vs normal/decreased }\end{array}$ & $\begin{array}{l}3.4(0.4-25.9) \\
4.8(1.7-13.2)\end{array}$ & $\begin{array}{l}0.24 \\
0.003^{*}\end{array}$ & $\begin{array}{c}1.8(0.4-8.1) \\
5.5(1.6-18.9)\end{array}$ & $\begin{array}{l}0.42 \\
0.007^{*}\end{array}$ & - & - \\
\hline \multicolumn{7}{|c|}{ C: Categorised ERCC1, also controls for p16 (p16-positive oropharyngeal tumour vs other) ${ }^{a}$} \\
\hline \multicolumn{7}{|l|}{ Hazard ratio } \\
\hline $\begin{array}{l}\text { Normal/increased vs decreased } \\
\text { Increased vs normal/decreased }\end{array}$ & $\begin{array}{l}3.4(0.4-25.5) \\
4.6(1.6-13.2)\end{array}$ & $\begin{array}{l}0.24 \\
0.004 *\end{array}$ & $\begin{array}{c}1.9(0.4-8.3) \\
5.2(1.5-18.3)\end{array}$ & $\begin{array}{l}0.40 \\
0.01 *\end{array}$ & - & - \\
\hline $\begin{array}{l}\text { Models were stratified by randomization strata (includi } \\
\text { aExploratory analysis, excluding } 8 \mathrm{~F} 1 \text { antibody based o } \\
{ }^{*} \text { Indicates statistical significance. }\end{array}$ & $\begin{array}{l}\text {-stage) and controlled for } \\
\text { ults of primary analysis ( } 3 \text { - }\end{array}$ & atment arm. & & & & \\
\hline
\end{tabular}

prognostic in a randomised study population treated homogeneously with cisplatin-radiotherapy and do not recommend this antibody for further development. This recommendation is in line with the recent contradiction of the original IALT findings in NSCLC with 8F1 (Friboulet et al, 2013).

Another barrier to routine use of semi-quantitative IHC for ERCC1-XPF protein expression is that an optimal cutpoint for clinical classification has not been established. To date, retrospective studies commonly divided their population at the median to compare outcomes for high vs low tumour expression. While an illustrative technique, the median split from one study cohort may not be reproducible or valid in a subsequent cohort. Further challenging the movement of an ERCC1-XPF measurement technique into the integral biomarker setting is validation of a scoring methodology against a standardised control. In the current study, evaluation of diagnostic FFPE tissue posed challenges similar to the routine clinical setting. Patients were treated at eight academic and community centers; variations in collection and processing were assumed to influence ERCC1 immunodetection and to be confounding. For this reason, we developed a standard operating procedure using an internal control. We scored tumour cells with reference to non-neoplastic basal epithelial cells, assuming that pre-analytic variables influencing ERCC1 antigen detection were identical for tumour and non-neoplastic cells within the same specimen. Both specific antibodies were prognostic using this methodology, strengthening confidence in its application; however, external validation in a separate cohort is required. 

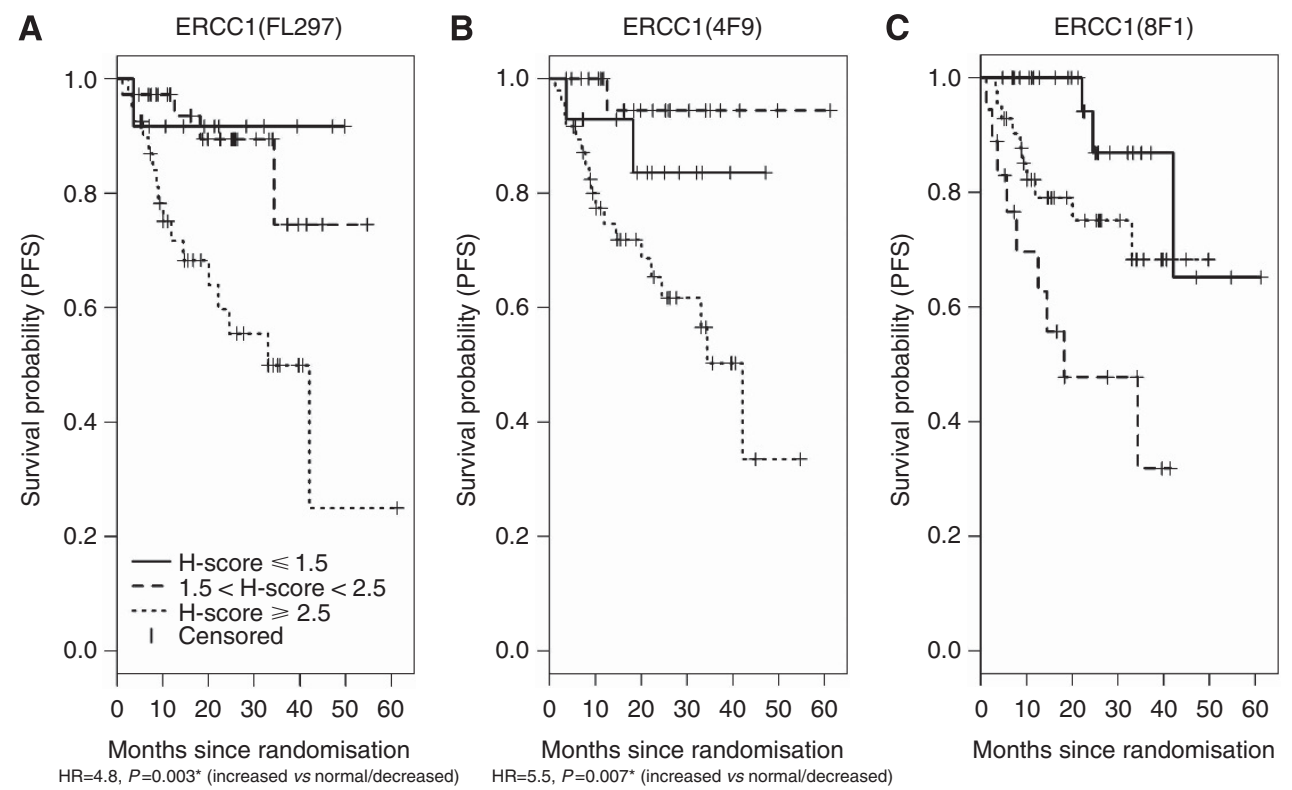

Figure 4. (A-C) Kaplan-Meier curves showing PFS as a function of categorical ERCC1. For the primary analysis, PFS was treated as a continuous variable. For purposes of graphical display, PFS is presented in Figure 4 for each antibody, according to pre-defined categories of ERCC1 expression: increased $(\mathrm{H}$-score $\geqslant 2.5)$, normal $(1.5<\mathrm{H}$-score $<2.5)$, or decreased $(\mathrm{H}$-score $\leqslant 1.5)$. Hazard ratios are presented for the exploratory cutpoint, 'increased' vs 'normal/decreased' ERCC1 expression as detected by the two specific antibodies. * Indicates statistical significance.
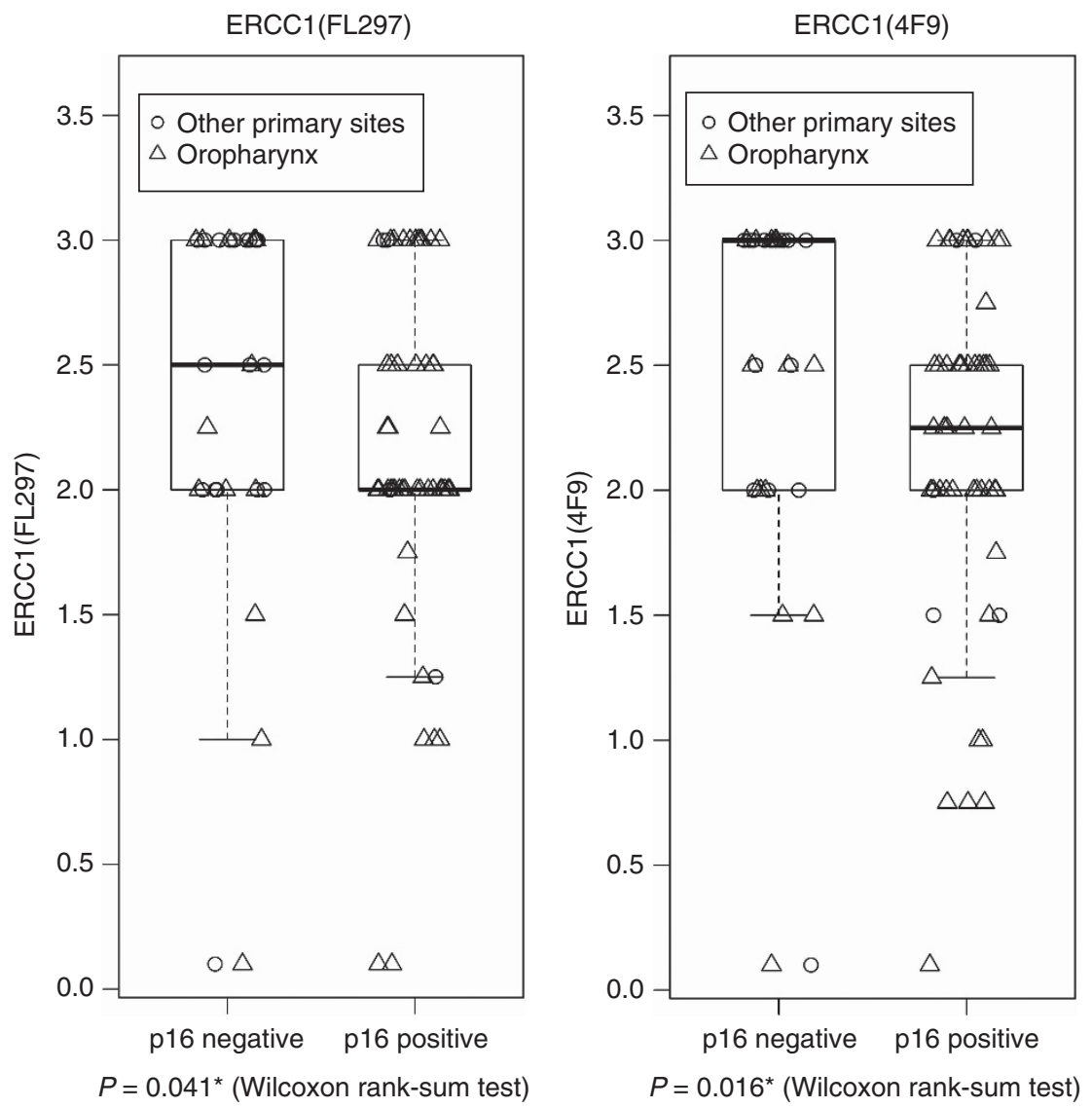

Figure 5. Distribution of ERCC1 by p16 expression. Boxplots present ERCC1 expression by p16 status, for the specific antibodies FL297 and 4 F9. Plotting characters identify tumour site category (oropharyngeal vs non-oropharyngeal). * Indicates statistical significance.

Two validated and specific antibodies, FL297 against ERCC1 (Hao et al, 2011) and SPM228 against XPF (Vaezi et al, 2011b), have been associated with PFS in small retrospective cohorts undergoing platinum-radiotherapy. The FL297 antibody is specific for ERCC1 and has been validated by multiple techniques (Bhagwat et al, 2009). However, an interpretive challenge with 
FL297 is the variable degree of cytoplasmic staining (so-called 'cytoplasmic bleed') occurring in both normal and ERCC1-XPFdeficient cells (Bhagwat et al, 2009). Because scoring must be restricted to the nucleus, the exclusive site of ERCC1-XPF function, background cytoplasmic staining increases the difficulty of interpretation. In this study, we simultaneously evaluated FL297 and the newly available 4F9 clone that demonstrated excellent agreement and were similarly prognostic. However, the 4F9 antibody produced crisp nuclear staining with little to no cytoplasmic bleed. Moreover, 4F9 is a monoclonal antibody, which ensures consistent antigenicity and sustainable production over time. As detailed experiments confirmed that 4F9 is also specific for ERCC1, in line with a recent report of its ultra-specificity (Ma et al, 2012), we recommend 4F9 for further development based upon ease of clinical interpretation.

The primary analysis focused upon proportional hazards regression with ERCC1 expression as a continuous variable. We also explored two pre-specified cutpoints to facilitate future clinical application: decreased/normal $v s$ increased expression and decreased $v s$ normal/increased expression. Of note, the former classification significantly distinguished patients with superior vs inferior PFS, whereas the alternate classification did not. More precisely stated, patients with greater ERCC1 protein expression in tumour cells than adjacent normal basal epithelial cells demonstrated inferior PFS. Of interest, this cutpoint also corresponded closely with the median split, as utilised in retrospective reports (Hao et al, 2011; Vaezi et al, 2011b). This cutpoint is clinically applicable and prognostic with two specific antibodies. External validation and investigation of inter-observer agreement are appropriate next steps.

This study has several limitations. First, although enrolled prospectively onto a randomised trial and treated homogeneously with cisplatin-radiotherapy, tissue was collected optionally and available for only 90/204 patients (44\%). Baseline characteristics were largely similar in patients with or without submitted tissue, with the exception that patients with oral cavity tumours were unlikely to have available tissue. While the oral cavity is associated with higher ERCC1-XPF expression than other mucosal sites (Vaezi et al, 2011b), the study population included only $7.5 \%$ oral cavity, in keeping with current guidelines favoring primary surgery for oral cavity tumours (Ang et al, 2010). Consequently, presented results are likely generalizable to the HNSCC population recommended for cisplatin-radiotherapy. Second, the scoring methodology required the presence of non-neoplastic basal epithelial cells within the primary tumour specimen. Although all submitted specimens met this requirement, the method would not be applicable to tissue from lymph node or other metastases. Third, the study population included both HPV-positive and -negative disease, increasingly studied separately because of striking prognostic differences (Ang et al, 2010). Because ERCC1 expression was significantly associated with p16 status in this population, a potential criticism is that ERCC1 expression was a mere proxy for HPV status. However, restricting analysis to p16-positive oropharyngeal cases indicated that ERCC1 expression added additional prognostic information in HPV-associated disease. Fourth, recent characterisation of four ERCC1 isoforms in the A549 NSCLC cell line indicated that only the ERCC1-202 isoform is functional in repairing cisplatin damage (Friboulet et al, 2013). As no current ERCC1 antibody is specific for this isoform, the authors challenge the clinical utility of ERCC1 characterisation by IHC. Although both FL297 and 4F9 detect the ERCC1-202 isoform, each detects at least two other isoforms, which appear not to function in repairing cisplatin DNA damage. Simultaneous detection of nonfunctional isoforms creates potential for categorical misclassification of tumour ERCC1 expression. Despite this acknowledged limitation, ERCC1 expression by FL297 and 4F9 demonstrated strong and concordant association with PFS in this study. The prognostic association is robust, clinically meaningful and in line with reports by others (Hao et al, 2011; Vaezi et al, 2011b). We hypothesise that detection of ERCC1-202 underlies prognostic performance; however, the biologic underpinnings of this clinical association require further elucidation. Future methodologies for specific detection of the ERCC1-202 isoform may prove to be superior biomarkers of clinical cisplatin resistance.

In summary, baseline ERCC1-XPF protein expression by FL297 or 4F9 is prognostic of PFS in patients with locally advanced HNSCC undergoing cisplatin-radiotherapy, irrespective of p16 status. The specific antibody $4 \mathrm{~F} 9$ warrants further clinical development as a prognostic biomarker, preferred over FL297 because of staining characteristics and qualitative ease of intepretation. The current study does not qualify ERCC1-XPF overexpression as a predictive biomarker of cisplatin resistance, as all patients received platinum. Investigating this hypothesis would require a randomised trial with stratification by ERCC1-XPF expression status, comparing cisplatin with a non-platinum alternative - such as docetaxel or cetuximab which radiosensitise through ERCC1-independent mechanisms (Huang et al, 1999; Milas et al, 1999). Such a trial could be justified should our findings, including the candidate cutpoint, be replicated in a separate cohort.

\section{ACKNOWLEDGEMENTS}

This biomarker substudy was partially funded by the original investigator-initiated clinical trial grant from Genentech, Inc. Additional support was provided by the Cancer Center Support Grants of the Fred Hutchinson/University of Washington Cancer Consortium (P30 CA015704) and the University of Pittsburgh Cancer Institute (P30 CA047904), as well as the UPCI Head and Neck Cancer SPORE (P50 CA097190-08).

\section{CONFLICT OF INTEREST}

The authors declare no conflict of interest.

\section{REFERENCES}

Adelstein DJ, Li Y, Adams GL, Wagner Jr. H, Kish JA, Ensley JF, Schuller DE, Forastiere AA (2003) An intergroup phase III comparison of standard radiation therapy and two schedules of concurrent chemoradiotherapy in patients with unresectable squamous cell head and neck cancer. J Clin Oncol 21(1): 92-98.

Ang KK, Harris J, Wheeler R, Weber R, Rosenthal DI, Nguyen-Tan PF, Westra WH, Chung CH, Jordan RC, Lu C, Kim H, Axelrod R, Silverman CC, Redmond KP, Gillison ML (2010) Human papillomavirus and survival of patients with oropharyngeal cancer. $N$ Engl J Med 363(1): 24-35.

Babic A, Loftin IR, Stanislaw S, Wang M, Miller R, Warren SM, Zhang W, Lau A, Miller M, Wu P, Padilla M, Grogan TM, Pestic-Dragovich L, McElhinny AS (2010) The impact of pre-analytical processing on staining quality for $\mathrm{H} \& \mathrm{E}$, dual hapten, dual color in situ hybridization and fluorescent in situ hybridization assays. Methods 52(4): 287-300.

Barnhart HX, Haber M, Song J (2002) Overall concordance correlation coefficient for evaluating agreement among multiple observers. Biometrics 58(4): 1020-1027.

Bernier J, Domenge C, Ozsahin M, Matuszewska K, Lefebvre JL, Greiner RH, Giralt J, Maingon P, Rolland F, Bolla M, Cognetti F, Bourhis J, Kirkpatrick A, van Glabbeke M. European Organization for R, Treatment of Cancer T (2004) Postoperative irradiation with or without concomitant chemotherapy for locally advanced head and neck cancer. N Engl J Med 350(19): 1945-1952.

Bhagwat NR, Roginskaya VY, Acquafondata MB, Dhir R, Wood RD, Niedernhofer LJ (2009) Immunodetection of DNA repair endonuclease ERCC1-XPF in human tissue. Cancer Res 69(17): 6831-6838.

Britten RA, Liu D, Tessier A, Hutchison MJ, Murray D (2000) ERCC1 expression as a molecular marker of cisplatin resistance in human cervical tumor cells. Int J Cancer 89(5): 453-457. 
Chiu TJ, Chen CH, Chien CY, Li SH, Tsai HT, Chen YJ (2011) High ERCC1 expression predicts cisplatin-based chemotherapy resistance and poor outcome in unresectable squamous cell carcinoma of head and neck in a betel-chewing area. J Transl Med 9: 31 .

Cooper JS, Pajak TF, Forastiere AA, Jacobs J, Campbell BH, Saxman SB, Kish JA, Kim HE, Cmelak AJ, Rotman M, Machtay M, Ensley JF, Chao KS, Schultz CJ, Lee N, Fu KK. Radiation Therapy Oncology Group I (2004) Postoperative concurrent radiotherapy and chemotherapy for high-risk squamous-cell carcinoma of the head and neck. N Engl J Med 350(19): 1937-1944.

Crawford SB, Kosinski AS, Lin HM, Williamson JM, Barnhart HX (2007) Computer programs for the concordance correlation coefficient. Comput Methods Programs Biomed 88(1): 62-74.

De Silva IU, McHugh PJ, Clingen PH, Hartley JA (2000) Defining the roles of nucleotide excision repair and recombination in the repair of DNA interstrand cross-links in mammalian cells. Mol Cell Biol 20(21): 7980-7990.

Fountzilas G, Bamias A, Kalogera-Fountzila A, Karayannopoulou G, Bobos M, Athanassiou E, Kalogeras KT, Tolis C, Tsekeris P, Papakostas P, Vamvouka C, Zaramboukas T, Kosmidis P, Zamboglou N, Misailidou D (2009) Induction chemotherapy with docetaxel and cisplatin followed by concomitant chemoradiotherapy in patients with inoperable non-nasopharyngeal carcinoma of the head and neck. Anticancer Res 29(2): 529-538.

Friboulet L, Olaussen KA, Pignon JP, Shepherd FA, Tsao MS, Graziano S, Kratzke R, Douillard JY, Seymour L, Pirker R, Filipits M, Andre F, Solary E, Ponsonnailles F, Robin A, Stoclin A, Dorvault N, Commo F, Adam J, Vanhecke E, Saulnier P, Thomale J, Le Chevalier T, Dunant A, Rousseau V, Le Teuff G, Brambilla E, Soria JC (2013) ERCC1 isoform expression and DNA repair in non-small-cell lung cancer. N Engl J Med 368(12): 1101-1110.

Handra-Luca A, Hernandez J, Mountzios G, Taranchon E, Lacau-St-Guily J, Soria JC, Fouret P (2007) Excision repair cross complementation group 1 immunohistochemical expression predicts objective response and cancerspecific survival in patients treated by Cisplatin-based induction chemotherapy for locally advanced head and neck squamous cell carcinoma. Clin Cancer Res 13(13): 3855-3859.

Hao D, Lau HY, Eliasziw M, Box A, Diaz R, Klimowicz AC, Shin B, Lees-Miller SP, Magliocco AM (2011) Comparing ERCC1 protein expression, mRNA levels, and genotype in squamous cell carcinomas of the head and neck treated with concurrent chemoradiation stratified by HPV status. Head \& neck 34(6): 785-791.

Hayes M, Lan C, Yan J, Xie Y, Gray T, Amirkhan RH, Dowell JE (2011) ERCC1 expression and outcomes in head and neck cancer treated with concurrent cisplatin and radiation. Anticancer Res 31(12): 4135-4139.

Henk JM (1997) Controlled trials of synchronous chemotherapy with radiotherapy in head and neck cancer: overview of radiation morbidity. Clin Oncol 9(5): 308-312.

Huang SM, Bock JM, Harari PM (1999) Epidermal growth factor receptor blockade with C225 modulates proliferation, apoptosis, and radiosensitivity in squamous cell carcinomas of the head and neck. Cancer Res 59(8): 1935-1940.

Jemal A, Siegel R, Xu J, Ward E (2010) Cancer statistics, 2010. CA Cancer J Clin 60(5): 277-300.

Jordan RC, Lingen MW, Perez-Ordonez B, He X, Pickard R, Koluder M, Jiang B, Wakely P, Xiao W, Gillison ML (2012) Validation of methods for oropharyngeal cancer HPV status determination in US cooperative group trials. Am J Surg Pathol 36(7): 945-954.

Jun HJ, Ahn MJ, Kim HS, Yi SY, Han J, Lee SK, Ahn YC, Jeong HS, Son YI, Baek JH, Park K (2008) ERCC1 expression as a predictive marker of squamous cell carcinoma of the head and neck treated with cisplatin-based concurrent chemoradiation. Br J Cancer 99(1): 167-172.

Kamangar F, Dores GM, Anderson WF (2006) Patterns of Cancer incidence, mortality, and prevalence across five continents: defining priorities to reduce cancer disparities in different geographic regions of the world. J Clin Oncol 24(14): 2137-2150.

Koh Y, Kim TM, Jeon YK, Kwon TK, Hah JH, Lee SH, Kim DW, Wu HG, Rhee CS, Sung MW, Kim CW, Kim KH, Heo DS (2009) Class III betatubulin, but not ERCC1, is a strong predictive and prognostic marker in locally advanced head and neck squamous cell carcinoma. Ann Oncol 20(8): 1414-1419.

Ma D, Baruch D, Shu Y, Yuan K, Sun Z, Ma K, Hoang T, Fu W, Min L, Lan ZS, Wang F, Mull L, He WW (2012) Using protein microarray technology to screen anti-ERCC1 monoclonal antibodies for specificity and applications in pathology. BMC Biotechnol 12(1): 88.
Martins RG, Parvathaneni U, Bauman JE, Sharma AK, Raez LE, Papagikos MA, Yunus F, Kurland BF, Eaton KD, Liao JJ, Mendez E, Futran N, Wang DX, Chai X, Wallace SG, Austin M, Schmidt R, Hayes DN (2013a) Cisplatinradiotherapy with or without erlotinib in locally advanced squamous cell carcinoma of the head and neck: A randomized phase II trial. J Clin Oncol 31(11): 1415-1421.

Martins RG, Parvathaneni U, Bauman JE, Sharma AK, Raez LE, Papagikos MA, Yunus F, Kurland BF, Eaton KD, Liao JJ, Mendez E, Futran N, Wang DX, Chai X, Wallace SG, Austin M, Schmidt R, Hayes DN (2013b) Cisplatin and Radiotherapy With or Without Erlotinib in Locally Advanced Squamous Cell Carcinoma of the Head and Neck: A Randomized Phase II Trial. J Clin Oncol 31(11): 1415-1421.

Milas L, Milas MM, Mason KA (1999) Combination of taxanes with radiation: preclinical studies. Semin Radiat Oncol 9(2 Suppl 1): 12-26.

Moeller BJ, Yordy JS, Williams MD, Giri U, Raju U, Molkentine DP, Byers LA, Heymach JV, Story MD, Lee JJ, Sturgis EM, Weber RS, Garden AS, Ang KK, Schwartz DL (2011) DNA repair biomarker profiling of head and neck cancer: Ku80 expression predicts locoregional failure and death following radiotherapy. Clin Cancer Res 17(7): 2035-2043.

Niedernhofer LJ, Bhagwat N, Wood RD (2007) ERCC1 and non-small-cell lung cancer. N Engl J Med 356(24): 2538-2540, author reply 2540-1.

Niedernhofer LJ, Garinis GA, Raams A, Lalai AS, Robinson AR, Appeldoorn E, Odijk H, Oostendorp R, Ahmad A, van Leeuwen W, Theil AF, Vermeulen W, van der Horst GT, Meinecke P, Kleijer WJ, Vijg J, Jaspers NG, Hoeijmakers JH (2006) A new progeroid syndrome reveals that genotoxic stress suppresses the somatotroph axis. Nature 444(7122): 1038-1043.

Olaussen KA, Dunant A, Fouret P, Brambilla E, Andre F, Haddad V, Taranchon E, Filipits M, Pirker R, Popper HH, Stahel R, Sabatier L, Pignon JP, Tursz T, Le Chevalier T, Soria JC, Investigators IB (2006) DNA repair by ERCC1 in non-small-cell lung cancer and cisplatin-based adjuvant chemotherapy. N Engl J Med 355(10): 983-991.

Palom Y, Suresh Kumar G, Tang LQ, Paz MM, Musser SM, Rockwell S, Tomasz M (2002) Relative toxicities of DNA cross-links and monoadducts: new insights from studies of decarbamoyl mitomycin C and mitomycin C. Chem Res Toxicol 15(11): 1398-1406.

Pignon JP, le Maitre A, Maillard E, Bourhis J. Group M-NC (2009) Meta-analysis of chemotherapy in head and neck cancer (MACH-NC): an update on 93 randomised trials and 17346 patients. Radiother Oncol 92(1): 4-14.

Siegel R, Naishadham D, Jemal A (2012) Cancer statistics, 2012. CA Cancer J Clin 62(1): 10-29.

Simon GR, Schell MJ, Begum M, Kim J, Chiappori A, Haura E, Antonia S, Bepler G (2012) Preliminary indication of survival benefit from ERCC1 and RRM1tailored chemotherapy in patients with advanced nonsmall cell lung cancer: evidence from an individual patient analysis. Cancer 118(9): 2525-2531.

Taillade L, Penault-Llorca F, Boulet T, Fouret P, Michiels S, Taranchon E, Mountzios G, Validire P, Domont J, Girard P, Grunenwald D, Le Chevalier T, Soria JC (2007) Immunohistochemichal expression of biomarkers: a comparative study between diagnostic bronchial biopsies and surgical specimens of non-small-cell lung cancer. Ann Oncol 18(6): 1043-1050.

Taylor CR, Levenson RM (2006) Quantification of immunohistochemistryissues concerning methods, utility and semiquantitative assessment II. Histopathology 49(4): 411-424.

Trotti A, Bellm LA, Epstein JB, Frame D, Fuchs HJ, Gwede CK, Komaroff E, Nalysnyk L, Zilberberg MD (2003) Mucositis incidence, severity and associated outcomes in patients with head and neck cancer receiving radiotherapy with or without chemotherapy: a systematic literature review. Radiother Oncol 66(3): 253-262.

Vaezi A, Feldman CH, Niedernhofer LJ (2011a) ERCC1 and XRCC1 as biomarkers for lung and head and neck cancer. Pharmacogenomics Pers Med 4: 47-63.

Vaezi A, Wang X, Buch S, Gooding W, Wang L, Seethala RR, Weaver DT, D’Andrea AD, Argiris A, Romkes M, Niedernhofer LJ, Grandis JR (2011b) XPF expression correlates with clinical outcome in squamous cell carcinoma of the head and neck. Clin Cancer Res 17(16): 5513-5522.

Zheng Z, Chen T, Li X, Haura E, Sharma A, Bepler G (2007) DNA synthesis and repair genes RRM1 and ERCC1 in lung cancer. N Engl J Med 356(8): 800-808.

This work is published under the standard license to publish agreement. After 12 months the work will become freely available and the license terms will switch to a Creative Commons AttributionNonCommercial-Share Alike 3.0 Unported License.

\section{Supplementary Information accompanies this paper on British Journal of Cancer website (http://www.nature.com/bjc)}

